\title{
REVIEW ARTIKEL : AKTIVITAS ANTIDEPRESAN DARI TANAMAN FAMILI RUBIACEAE
}

\author{
${ }^{1}$ Ika Kartikasari, ${ }^{2}$ Kusnandar Anggadiredja, ${ }^{3}$ Risa Susanti
}

1,3Jurusan Farmasi Fakultas Matematika dan Ilmu Pengetahuan Alam, Universitas Garut ${ }^{2}$ Sekolah Farmasi Institut Teknologi Bandung

Info Article ABSTRAK

Submitted :

09 Oktober 2020

\section{Revised :}

08 Juli 2021

\section{Accepted :}

27 Juli 2021

\section{Corresponding Author :}

Ika Kartikasari

\section{Email :}

ikakartikasari123@gmail.com

Depresi merupakan penyakit gangguan mental yang ditandai dengan perasaan tertekan secara terus-menerus yang dapat mempengaruhi suasana hati, perilaku maupun kesehatan fisiknya. Depresi dapat berdampak pada menurunnya produktivitas kerja, ketergantungan narkotika dan psikotropika, gangguan dalam hubungan sosisal bahkan sampai menyebabkan bunuh diri. Obatobat depresi yang biasa digunakan adalah obat-obat sintetik dimana obat-obat antidepresan ini menimbulkan beberapa efek samping diantaranya hipotensi, kejang, mulut kering, mual muntah, serta penglihatan kabur sehingga untuk menghindari kondisi tersebut maka digunakan pengobatan alternatif dari tanaman famili Rubiaceae yang berpotensi sebagai antidepresan. Penelitian ini bertujuan untuk mengetahui tanaman-tanaman yang berpotensi sebagai antidepresan dari famili Rubiaceae. Metode yang digunakan yaitu dengan melakukan studi pustaka terkait dengan tanaman famili Rubiaceae yang memiliki aktivitas antidepresan yang terdapat pada jurnal yang bertaraf nasional maupun internasional yang diterbitkan dalam 10 tahun terakhir. Dari hasil penelitian terdapat 7 tanaman famili Rubiaceae yang memiliki potensi sebagai antidepresan diantaranya tanaman Morinda citrifolia Linn, Coffea sp, Uncaria rhynchophylla, Uncaria lanosa Wallich var. appendiculata Ridsd, Mitragyna speciosa Korth, hamelia patents, dan Nuclea latifolia Smith. Tanaman yang memiliki aktivitas antidepresan yang paling besar yaitu tanaman Coffea sp, Uncaria rhynchophylla dan Mitragyna speciosa Korth dengan dosis $10 \mathrm{mg} / \mathrm{kg}$. Dengan disusunya review artikel ini diharapkan dapat memberikan informasi terkait tumbuhan yang memiliki aktivitas antidepresan dari tanaman famili Rubiaceae yang bisa digunakan sebagai alternatif pengobatan depresi Kata kunci: Antidepresan, Rubiaceae.

\section{Access this article}

回地回

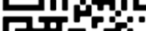

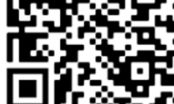

SCAN ME

\section{ABSTRACT}

Depression is a mental disorder characterized by constant feelings of stress which can affect mood, behavior and physical health. Depression may cause decrease work productivity, dependence on narcotics and psychotropic substances, disturbances in social relationships and even suicide. Depression drugs commonly used are synthetic drugs where these antidepressant drugs cause several side effects including hypotension, seizures, dry mouth, 
nausea, vomiting and blurred vision so that to avoid this condition, alternative treatments from plants of the Rubiaceae family are used that have the potential. as an antidepressant. This study aims to determine which plants have potential as antidepressants from the Rubiaceae family. The method used is by conducting literature studies related to plants of the Rubiaceae family, which have antidepressant activity in national and international journals published in the last 10 years. From the research results, there are 7 plants of the Rubiaceae family that have potential as antidepressants including Morinda citrifolia Linn, Coffee $s p$, Uncaria rhynchophylla, Uncaria lanosa Wallich var. appendiculata Ridsd, Mitragyna speciosa Korth, hamelia patents, dan Nuclea latifolia Smith. Tanaman yang memiliki aktivitas antidepresan yang paling besar yaitu tanaman Coffee sp, Uncaria rhynchophylla dan Mitragyna speciosa Korth dengan dosis $10 \mathrm{mg} / \mathrm{kg}$. By compiling this review article, it is hoped that it can provide information regarding plants that have antidepressant activity from plants of the Rubiaceae family that can be used as an alternative treatment for depression.

Keywords: Antidepressant, Rubiaceae.

\section{PENDAHULUAN}

World Health Organization (WHO) menyebutkan bahwa depresi merupakan gangguan mental yang ditandai dengan perasaan sedih, perasaan bersalah, hilangnya minat atau kesenangan, gangguan tidur, gangguan pola makan, juga konsentrasi yang buruk serta depresi yang paling parah dapat menyebabkan bunuh diri. Terdapat 322 juta orang di dunia menderita depresi, dimana hal tersebut setara dengan $4,4 \%$ populasi dunia serta pada tahun 2015 diperkirakan ada 788.000 orang meninggal akibat bunuh diri (Word Health Organization, 2017).

Depresi adalah salah satu penyakit gangguan mental yang ditandai dengan perasaan yang tertekan secara terusmenerus hal ini dapat mempengaruhi suasana hati, perilaku ataupun kesehatan fisiknya (Zhao et al., 2014). Depresi ini dapat menimbulkan penurunan produktivitas kerja, ketergantungan psikotropika atau narkotika, gangguan dalam hubungan sosial (Puspitasari, 2017), bahkan dampak yang paling buruk dapat menyebabkan bunuh diri (Geng et al., 2019). Ketika dilihat dari sisi biologis depresi menyebabkan adanya beberapa gangguan pada neurotransmitter norefinefrin, serotonin dan dopamin (Istriningsih et al., 2018). Depresi dapat disebabkan oleh beberapa faktor seperti genetika, biokimia, faktor lingkungan dan psikologis tetapi kadang-kadang dapat muncul tanpa alasan atau pemicu yang jelas (Tee \& Hassan, 2011).

Menurut riset kesehatan dasar tahun 2018 prevalensi yang terkena depresi di Indonesia pada usia lebih dari 15 tahun mencapai $6,1 \%$. Provinsi yang prevalensi depresi tertinggi adalah Sulawesi Tengah dengan total $12,3 \%$ dan provinsi Jambi memiliki prevalensi terendah yaitu sebesar 1,8\% sedangkan Jawa Barat menempati posisi ke 9 dari 33 provinsi dengan jumlah prevalensi sebesar 7,8\%. Penderita depresi 
yang menjalani pengobatan medis hanya 9\% dan sisanya 91\% tidak menjalani pengobatan medis (RISKESDAS, 2018).

Pada umumnya obat-obat antidepresan ini dibagi menjadi empat golongan besar diantaranya Selektive Serotonin Reuptake Inhibitor(SSRI) contoh obatnya yaitu citalopram, fluvoxamine, fluoxetine, escitalopram, paroxetin dan sentraline. Selanjutnya Serotonin Norephonephrine Reuptake Inhibitor (SNRI) contoh obatnya Venlafaxine dan duloxentine, Trycyclic Antidepressant (TCA) contoh obatnya amoxapine, imipramine, desimipramine, dan Monoamine Oxidase Inhibitor (MAO) contoh obatnya phenelzine (Katzung et al., 2013).

Obat antidepresan ini dapat memperbaiki gejala yang diderita pasien, hanya saja terdapat beberapa beberapa efek samping yang dapat muncul seperti retensi urin, konstipasi, penglihatan kabur, takikardia, mulut kering, hipotensi ortostatik, mual dan muntah (DiPiro et al., 2015).

Famili Rubiaceae merupakan salah satu famili yang beberapa jenis tanamannya telah digunakan sebagai obat tradisional. Famili Rubiaceae ini memiliki kurang lebih 13.673 spesies yang tersebar di 609 genus (Moraes et al., 2020) dan dapat ditemukan di kawasan tropis dan subtropis. Famili Rubiaceae ini terdiri dari 10 subfamili yaitu Rubia, Cinchona, Coffea, Morinda, Ixora, Mussaenda, Gardenia, Uncaria, Uragoga dan Pausingstalia (Lubis, 2008). Tanaman dari famili Rubiaceae secara empiris banyak digunakan oleh masyarakat sebagai obat malaria (Arnida et al., 2019), ramuan obat penyakit kanker, mengurangi nafsu makan, mengobati diare (Yusniah et al., 2019), menyembuhkan radang serta menguatkan imunitas (Dirgantara et al., 2013). Beberapa penelitian juga menyebutkan beberapa efek farmakologi dari tanaman famili Rubiaceae ini memiliki aktivitas sebagai stimulan, antidepresan, analgetik, antioksidan, antiinflamasi, serta antibakteri (Luliana \& Islamy, 2018).

Berdasarkan latar belakang diatas, dengan disusunya review artikel ini diharapkan dapat memberikan informasi terkait tumbuhan yang memiliki aktivitas antidepresan dari tanaman famili Rubiaceae yang bisa digunakan sebagai alternatif pengobatan depresi.

\section{METODE PENELITIAN}

Metode yang digunakan untuk pembuatan artikel reviewini yaitu dengan melakukan studi pustaka. Pustaka yang digunakan merupakan jurnal ilmiah yang terpercaya serta diterbitkan 10 tahun terakhir. Jurnal yang digunakan merupakan jurnal yang bertaraf nasional maupun internasional yang berkaitan dengan aktivitas antidepresan, tumbuhan famili Rubiaceae, serta metode forced swimming test dan tail suspension test. Pencarian artikel dilakukan dengan cara mencari sumber artikel yang didapatkan dengan melakukan pencarian di google scholar sebanyak, PubMed dan Science Direct dengan menggunakan kata kunci "antidepresan", "antidepressant", "famili Rubiaceae", "mice", "metode forced swimming test" dan "metode tail suspension test". 


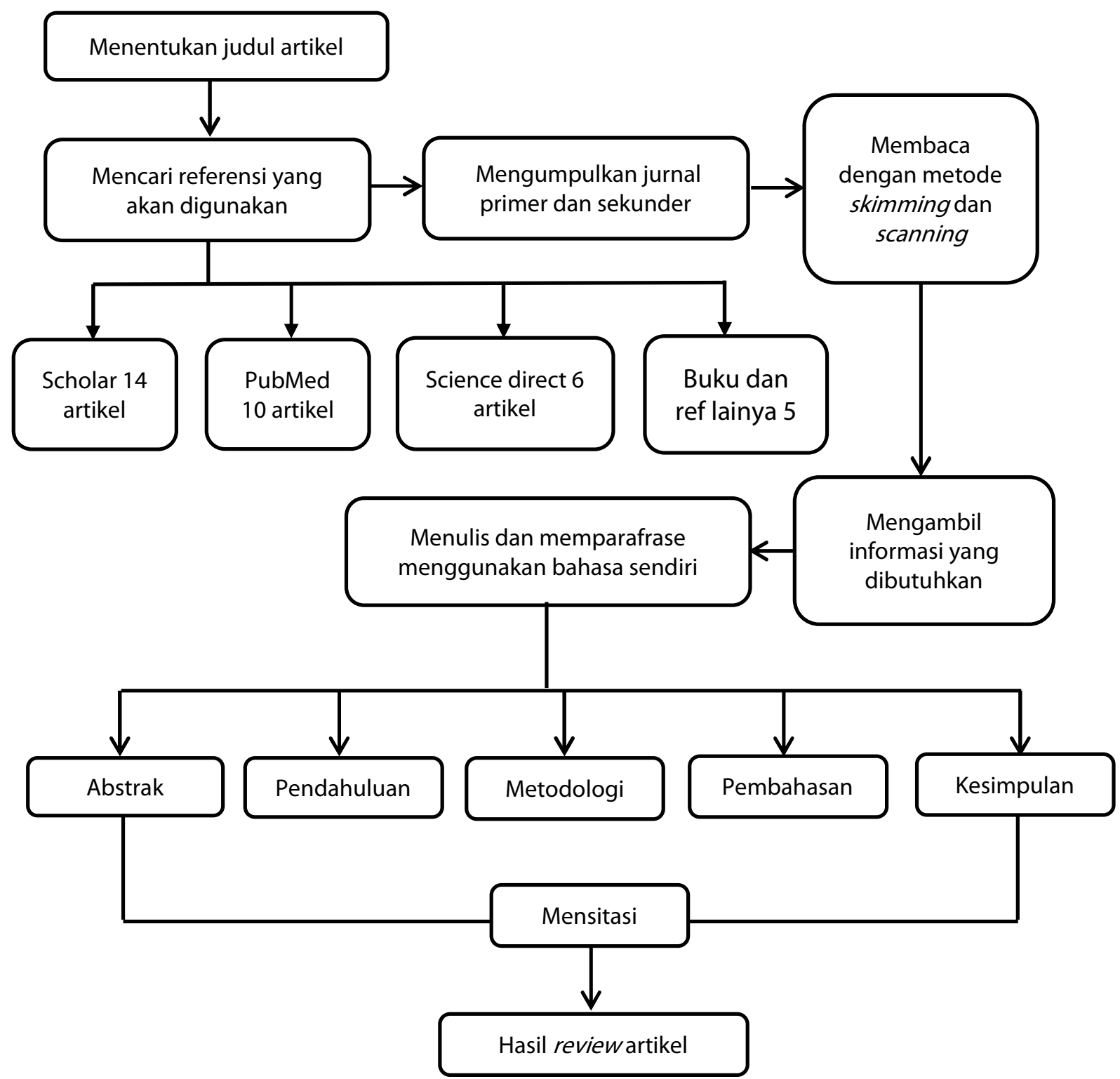

\section{HASIL DAN PEMBAHASAN}

Hasil telaah dari berbagai jurnal didapatkan beberapa tanaman famili Rubiaceae dimana tanaman tersebut memiliki senyawa yang mempunyai aktivitas sebagai antidepressan. Beberapa tanaman yang memiliki aktivitas antidepresan diantaranya yaitu Morinda citrifolia, Coffea sp, Uncaria rhynchophylla, Uncaria lanosa Wallich var. appendiculata Ridsd, Mitragyna speciosa, Hamelia patents, Nuclea latifolia Smith. Hasil lengkap ditunjukkan pada Tabel 1. 
Tabel 1. Nama tanaman obat, bagian yang digunakan, kandungan senyawa aktif, dosis dan hewan uji

\begin{tabular}{|c|c|c|c|c|c|c|c|}
\hline No & $\begin{array}{c}\text { Nama } \\
\text { Tanaman } \\
\text { Obat } \\
\end{array}$ & $\begin{array}{c}\text { Bagian } \\
\text { Yang } \\
\text { Dipakai }\end{array}$ & $\begin{array}{c}\text { Preparasi } \\
\text { Sampel }\end{array}$ & $\begin{array}{c}\text { Kandungan } \\
\text { Senyawa } \\
\text { Aktif }\end{array}$ & $\begin{array}{l}\text { Dosis } \\
\text { Efektif }\end{array}$ & $\begin{array}{c}\text { Hewan } \\
\text { Uji }\end{array}$ & Ref \\
\hline 1 & $\begin{array}{l}\text { Morinda } \\
\text { citrifolia Linn. } \\
\text { (Mengkudu) }\end{array}$ & Buah & $\begin{array}{l}\text { Ekstrak } \\
\text { metanol }\end{array}$ & 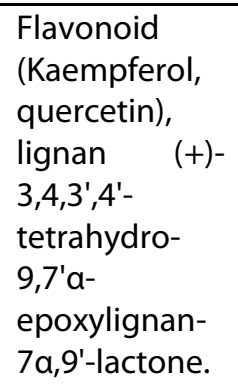 & $\begin{array}{l}500-750 \\
\mathrm{mg} / \mathrm{kg}\end{array}$ & Mencit & $\begin{array}{l}\text { (Narasing } \\
\text { am et al., } \\
2017)\end{array}$ \\
\hline 2 & $\begin{array}{l}\text { Coffea } \quad s p . \\
\text { (Kopi) }\end{array}$ & Biji & $\begin{array}{l}\text { Kafein } \\
\text { dilarutkan } \\
\text { dalam } \mathrm{NaCl} \\
0,9 \%\end{array}$ & Kafein & $\begin{array}{l}10-50 \\
\mathrm{mg} / \mathrm{kg}\end{array}$ & Mencit & $\begin{array}{l}\text { (Szopa et } \\
\text { al., 2016) }\end{array}$ \\
\hline \multirow[t]{3}{*}{3} & $\begin{array}{l}\text { Uncaria } \\
\text { rhynchophylla } \\
\text { (Miq.) Miq. ex }\end{array}$ & $\begin{array}{l}\text { Batang } \\
\text { dan kait }\end{array}$ & $\begin{array}{l}\text { Ekstrak } \\
\text { etanol }\end{array}$ & $\begin{array}{l}\text { Flavanol } \\
\text { (katekin, } \\
\text { epikatekin) }\end{array}$ & $\begin{array}{l}20-80 \\
\mathrm{mg} / \mathrm{kg}\end{array}$ & Mencit & $\begin{array}{l}\text { (Geng et } \\
\text { al., 2019) }\end{array}$ \\
\hline & $\begin{array}{l}\text { Havil. } \\
\text { (Gouteng) }\end{array}$ & & $\begin{array}{l}\text { Isorhynch } \\
\text { ophylline }\end{array}$ & $\begin{array}{l}\text { Isorhynchop- } \\
\text { hylline }\end{array}$ & $\begin{array}{l}10-40 \\
\mathrm{mg} / \mathrm{kg}\end{array}$ & & $\begin{array}{l}\text { (Xian et } \\
\text { al., 2016) }\end{array}$ \\
\hline & $\begin{array}{l}\text { (Xian et al., } \\
2016)\end{array}$ & & $\begin{array}{l}\text { Disuspensi- } \\
\text { kan dalam } \\
0,5 \% \\
\text { natrium } \\
\text { karboksi- } \\
\text { metil } \\
\text { selulosa }\end{array}$ & & & & \\
\hline 4 & $\begin{array}{l}\text { Uncaria lanosa } \\
\text { Wallich var. } \\
\text { Appendicu- } \\
\text { lata Ridsd }\end{array}$ & $\begin{array}{l}\text { Batang, } \\
\text { kait }\end{array}$ & $\begin{array}{l}\text { Ekstrak } \\
\text { etanol }\end{array}$ & $\begin{array}{l}\text { Rhynchophy- } \\
\text { lline }\end{array}$ & $\begin{array}{l}62,5- \\
500 \\
\mathrm{mg} / \mathrm{kg}\end{array}$ & Mencit & $\begin{array}{l}\text { (Hsu et al., } \\
\text { 2012) }\end{array}$ \\
\hline 5 & $\begin{array}{l}\text { Mitragyna } \\
\text { speciosa } \\
\text { Korth. } \\
\text { (Kratom) }\end{array}$ & Daun & $\begin{array}{l}\text { Mitragy- } \\
\text { nine } \\
\text { dilarutkan } \\
\text { dalam 20\% } \\
\text { Tween } 80\end{array}$ & Mitragynine & $\begin{array}{l}10-30 \\
\mathrm{mg} / \mathrm{kg}\end{array}$ & Mencit & $\begin{array}{l}\text { (Idayu et } \\
\text { al., 2011) }\end{array}$ \\
\hline 6 & $\begin{array}{l}\text { Hamelia } \\
\text { patens Jacq. } \\
\text { (Firebush) }\end{array}$ & Batang & $\begin{array}{l}\text { Ekstraksi } \\
\text { kloroform } \\
\text { dan } \\
\text { metanol }\end{array}$ & $\begin{array}{l}\text { alkaloid indol, } \\
\text { amida dan } \\
\text { steroid. }\end{array}$ & $\begin{array}{l}100- \\
200 \\
\mathrm{mg} / \mathrm{kg}\end{array}$ & Mencit & $\begin{array}{l}\text { (Surana \& } \\
\text { Wagh, } \\
\text { 2017) }\end{array}$ \\
\hline 7 & $\begin{array}{l}\text { Nuclea latifolia } \\
\text { Smith. }\end{array}$ & Akar & Ekstrak air & $\begin{array}{l}\text { Flavonoid, } \\
\text { nauclamides } \\
\text { A-E, alkaloid } \\
\text { indol, } \\
\text { saponin, } \\
\text { tanin, fenol, } \\
\text { strictosamide }\end{array}$ & $\begin{array}{l}16-160 \\
\mathrm{mg} / \mathrm{kg}\end{array}$ & Mencit & $\begin{array}{l}\text { (Taïwe et } \\
\text { al., 2011) }\end{array}$ \\
\hline
\end{tabular}

Terdapat beberapa jenis tanaman dari famili Rubiaceae serta senyawasenyawa aktifnya yang memiliki potensi sebagai antidepresan diantaranya yaitu senyawa flavonoid seperti kaempferol, quercetin, katekin dan epikatekin; senyawa alkaloid seperti isorhynchophylline, rhynchophylline, mitragynine dan kafein; saponin; tanin; fenol; lignan (+)-3,4,3',4'tetrahydro-9,7'a-epoxylignan-7a,9'- 
lactone; amida; steroid; naucalmides A-E; dan strictosamide. Senyawa flavonoid yang terdapat pada beberapa jenis tanaman diketahui memiliki aktivitas sebagai antidepresan dimana senyawa flavonoid ini bekerja dengan menghambat aktivitas MAO, meningkatkan serotonin (5$\mathrm{HT}$ ), norepinefrin (NE), dan kadar BrainDerived Neurotrophic Factor (BDNF) (Azis \& Lawan, 2020). Pada tanaman Morinda citrifolia Linn. atau mengkudu terdapat tiga senyawa aktif yang bekerja sebagai antidepresan diantaranya kaempferol, quercetin serta satu lignan ((+)-3,4,3',4'tetrahydro-9,7'a-epoxylignan-7a,9'lactone).

Kaempferol dan quercetin merupakan dua senyawa yang termasuk kedalam golongan flavonoid dimana kedua senyawa tersebut merupakan penghambat MAO-A dan MAO-B yang kuat. Hal inilah yang menunjukkan bahwa buah mengkudu merupakan penghambat MAO-A dan MAO-B alami, hal tersebut mengakibatkan efek yang sinergis dari beberapa komponen aktif (Deng \& West, 2011). Pemberian ekstrak metanol Morinda citrifolia Linn pada hewan uji dengan dosis $500 \mathrm{mg} / \mathrm{kg}$ yang diberikan secara oral mampu memberikan efek yang signifikan yaitu dengan menurunkan durasi imobilitas pada hewan yang diuji dengan menggunakan metode tail suspension test (TST) (Narasingam et al., 2017). Pada salah satu penelitian lain disebutkan bahwa pada ekstrak etil asetat buah mengkudu yang dilakukan pengujian secara in vitro memiliki aktivitas antidepresan dengan cara menghambat MAO-A (78\%) dan MAOB (49\%) (Deng \& West, 2011). Penghambatan tersebut mengakibatkan terjadinya peningkatan konsentrasi noerpinefrin, serotonin dan dopamin dalam neuron (Harvey \& Champe, 2013).

Senyawa lain yang berpotensi sebagai antidepresan yaitu kafein. Kafein merupakan zat yang paling sering konsumsi di dunia, dengan sekitar $80 \%$ dikonsumsi dalam bentuk kopi (Lucas et al., 2011). Pada salah satu penelitian, pemberian kafein dosis $10 \mathrm{mg} / \mathrm{kg}$ pada secara signifikan dapat mengurangi waktu imobilitas dibandingkan kelompok kontrol serta dosis tertingginya dapat memberikan efek yang mirip dengan pemberian imipramin 30 mg/kg (Szopa et al., 2016). Senyawa kafein ini bekerja dengan cara memblokir subunit reseptor adenosin A1 dimana hal tersebut dapat meningkatkan kadar ketokolamin dan serotonin (5-HT) di sistem saraf pusat (SSP) (Szopa et al., 2016). Senyawa kafein juga memiliki meknisme kerja lain yaitu sebagai penghambat MAOB (Dey \& Mukherjee, 2018). Berdasarkan penelitian lain, kafein yang diberikan pada hewan yang terpapar CUS (chronic unpredictable stress) menunjukkan efek antidepresan yang ditandai dengan peningkatan dopamin dan serotonin (Pechlivanova et al., 2012).

Flavanol merupakan jenis flavonoid, yang termasuk kedalam senyawa flavanol diantaranya yaitu katekin dan epikatekin. Katekin dan epikatekin adalah senyawa yang memiliki potensi sebagai antidepresan dengan mekanisme kerja menghambat monoamin oksidase $B$ (MAO-B). Katekin menghasilkan efek dengan menjadikan reseptor melatonin sebagai targetnya. Katekin juga menunjukan aktivitas yang lebih kuat dibandingkan epikatekin dalam menahan resptor MT1 dan MT2 (Geng et al., 2019). 
Isorhynchophylline adalah hasil isolasi dari Uncaria rhynchophylla (Miq.) Miq. ex Havil. yang merupakan suatu golongan alkaloid. Senyawa alkaloid menunjukkan aktivitas sebagai antidepresan dengan menghambat pengambilan serotonin di otak (Pradiningsih et al., 2017). Pada penelitian lain, senyawa isorhynchophylline yang diuji dengan menggunakan metode FST dan TST pada dosis $10 \mathrm{mg} / \mathrm{kg}$ dapat memberikan aktivitas sebagai antidepresan yang ditandai dengan menurunnya waktu imobiltas jika dibandingkan dengan kelompok kontrol. Isorhynchophylline bekerja dengan cara meningkatkan neurotransmiter monoamine termasuk noepinefrin (NE) dan serotonin (5-HT) serta menghambat aktivitas monoamin oksidase A (MAO-A) (Xian et al., 2016).

Rhynchophylline merupakan senyawa yang dapat mempengaruhi kadar serotonin di korteks, striatum, hipokampus dan hipotalamus (Hsu et al., 2012). Senyawa rhynchophylline ini termasuk kedalam golongan alkaloid utama dari spesies Uncaria (Wang et al., 2010). Rhynchophylline yang terkandung dalam ekstrak etanol Uncaria lanosa merupakan senyawa aktif dengan jumlah yang paling besar dibandingkan dengan 3 spesies uncaria lain diantaranya Uncaria rhynchophylla (Miquel) Jacks, Uncaria hirsuta Haviland, Uncaria lanosa Wallich var. appendiculata Ridsd.

Ekstrak etanol Uncaria lanosa menunjukkan aktivitas antidepresan pada hewan yang di uji dengan menggunakan pengujian FST dan TST yaitu ditandai dengan adanya penurunan waktu imobilitas. Mekanisme kerja dari tanaman
Uncaria lanosa Wallich var. appendiculata Ridsd. yaitu meningkatkan kadar monoamina, khususnya serotonin (5-HT) dan norepinefrin (NE) serta menghambat aktivitas monoamin oksidase A (MAO-A) (Hsu et al., 2012).

Mitragynine merupakan kandungan senyawa utama yang terdapat pada daun Mitragyna speciosa yang termasuk kedalam golongan alkaloid indol (Idayu et al., 2011). Mitragynine yang diuji dengan menggunakan metode Forced Swimming Test (FST) dan Tail Suspension Test (TST) yang diberikan kepada hewan dengan dosis $10 \mathrm{mg} / \mathrm{kg}$ dan di suntikan secara intra peritoneal (i.p) dapat mengurangi waktu imobilitas. Hal tersebut menunjukkan bahwa senyawa mitragynine terbukti memiliki aktivitas sebagai antidepresan. Mitragynine juga secara signifikan dapat mengurangi konsentrasi kortikosteron pada hewan yang dilakukan pengujian FST dan TST, efek tersebut dimediasi oleh interaksi dengan sistem sumbu hipotalamus hipofisis adrenal (HPA) dalam sistem neuroendokrin. Sumbu HPA dalam sistem neuroendokrin adalah salah satu mekanisme neurobiologis yang berperan penting dan mirip dengan sistem neurotransmiter monoamin dalam pengobatan antidepresan. Disfungsi atau hiperaktivitas sistem sumbu HPA memberikan indikator depresi yang siginfikan dalam menanggapi stres yang tergambar dari kelebihannya produksi hormon glukokortikoid terutama kortikosteron pada hewan dan kortisol pada manusia (Idayu et al., 2011).

\begin{tabular}{llr}
\multicolumn{2}{c}{ Kandungan senyawa } & yang \\
menujukkan aktivitas & sebagai \\
antidepresan pada tanaman & Hamelia \\
patents adalah Alkaloid indol, amida dan
\end{tabular}


steroid (Surana \& Wagh, 2017). Alkaloid indol memiliki efek terapeutik seperti antiinflamasi, penghambat fosfodiesterase, agonis dan antagonis reseptor 5-HT (Hamid et al., 2017).

Ekstrak air Nuclea latifolia dosis 16 $\mathrm{mg} / \mathrm{kg}$ secara signifikan mampu menurunkan waktu imobilitas pada hewan yang diuji dengan menggunakan metode forced swimming test, hal tersebut menujukkan bahwa tanaman tersebut memiliki efek sebagai antidepresan dengan cara mengaktivasi GABAergic atau dengan memodulasi tingkat serotonergik dalam sistem saraf pusat (Taïwe et al., 2011). Berdasarkan penelitian lain tanaman Nuclea latifolia mengandung senyawa strictosamide dimana senyawa tersebut merupakan penghambat MAO-A yang lemah (Boucherle et al., 2016).

Metode pengujian yang digunakan pada penelitian ini yaitu forced swimming test dan tail suspension test. Efek antidepresan pada metode Forced Swimming Test dapat diukur melalui lama imobility time atau waktu dimana hewan tidak bergerak dibandingkan dengan kelompok yang tidak diberikan obat antidepresan (Swati et al., 2013). Pada metode forced swimming test hewan uji dipaksa untuk berenang dalam wadah dengan diameter $10 \mathrm{~cm}$ dan tinggi $25 \mathrm{~cm}$ serta berisi air $19 \mathrm{~cm}$ dengan suhu $25^{\circ} \mathrm{C}$ (Zheng et al., 2013), awalnya hewan uji akan berenang secara aktif (mobility) tetapi pada akhirnya hewan uji tersebut akan meperlihatkan keaadaan imobilitas (keadaan tidak bergerak). Penurunan waktu imobilitas selama pengujian diambil sebagai ukuran aktvitas antidepresan. (Shewale et al., 2012). Metode tail suspension testjuga merupakan suatu cara untuk memodelkan kondisi depresi. Caranya adalah dengan menggantungkan hewan $50 \mathrm{~cm}$ diatas lantai, dengan kriteria immobile terjadi ketika hewan tidak bergerak selama lebih dari 5 detik (Narasingam et al., 2017).

\section{KESIMPULAN}

Berdasarkan hasil studi pustaka terdapat beberapa tanaman dari famili Rubiaceae yang memiliki aktivitas sebagai antidepresan. Senyawa Aktif yang berperan sebagai antidepresan diantaranya yaitu senyawa flavonoid, kaempferol, quercetin, lignan (+)-3,4,3',4'tetrahydro-9,7'a-epoxylignan-7a,9'-

lactone, kafein, flavanol (katekin dan epikatekin), isorhynchophylline, mitragynine, alkaloid indol, amida, steroid, naucalmides $\mathrm{A}-\mathrm{E}$, saponin, tanin, fenol dan strictosamide. Dari 7 tanaman terdapat beberapa tanaman yang memiliki aktivitas antidepresan yang paling tinggi diantaranya yaitu Coffea sp, Uncaria rhynchophylla dan Mitragyna speciosa Korth dengan dosis yang sama yaitu 10 $\mathrm{mg} / \mathrm{kg}$.

\section{UCAPAN TERIMA KASIH}

Peneliti mengucapkan terima kasih kepada Bapak Dr. Apt. Kusnandar Anggadiredja, M.Si selaku pembimbing utama dan kepada lbu Apt. Risa Susanti, M.S.Farm selaku pembimbing serta atas bimbingannya, serta seluruh pihak yang telah terlibat dalam pembuatan review artikel ini.

\section{DAFTAR PUSTAKA}

Arnida, A., Sutomo, S., \& Rosyidah, L. (2019). Aktivitas Penghambatan Polimerisasi Hem Dari Fraksi Etil Asetat Daun Manuran, Coptosapelta tomentosa Valeton ex K.Heyne (Rubiaceae). Jurnal 
Fitofarmaka Indonesia, 6(1), 309-314. https://doi.org/10.33096/jffi.v6i1.459

Azis, A., \& Lawan, G. R. (2020). Jurnal Kesehatan Yamasi Makassar. 4(1), 98-110.

Boucherle, B., Haudecoeur, R., Queiroz, E. F., De Waard, M., Wolfender, J. L., Robins, R. J., \& Boumendjel, A. (2016). Nauclea latifolia: Biological activity and alkaloid phytochemistry of a West African tree. Natural Product Reports, 33(9), 10341043.

Deng, S., \& West, B. (2011). Antidepressant effects of Noni fruit and its active principals. Asian Journal of Medical Sciences, 3(2), 79-83.

Dey, A., \& Mukherjee, A. (2018). Plant-Derived Alkaloids: A Promising Window for Neuroprotective Drug Discovery. In Discovery and Development of Neuroprotective Agents from Natural Products: Natural Product Drug Discovery. Elsevier Inc.

DiPiro, J. T., Wells, B. G., Schwinghammer, T. ., \& DiPiro, C. V. (2015). Pharmacotherapy Handbook, Ninth Edition. In McGrawHill Education Companies, Inggris.

Dirgantara, S., Nawawi, A., \& Insanu, M. (2013). Uji Aktivitas Antioksidan Tiga Spesies Tanaman Sarang Semut (Famili: Rubiaceae) Asal Kabupaten Merauke, Papua. Jurnal Biologi Papua, 5(April), 10-14.

Geng, C., Yang, T., Huang, X., Ma, Y., \& Zhang, X. (2019). Antidepressant potential of Uncaria rhynchophylla and its active flavanol , catechin, targeting melatonin receptors. Journal of Ethnopharmacology, 232(2019), 3946.

Hamid, H. A., Ramli, A. N. M., \& Yusoff, M. M. (2017). Indole alkaloids from plants as potential leads for antidepressant drugs: A mini review. Frontiers in Pharmacology, 8(96), 1-7.

Harvey, R., \& Champe, P. (2013). Farmakologi Ulasan Bergambar Edisi 4. EGC, Jakarta, 165-173.

Hsu, L., Ko, Y., Cheng, H., Chang, C., Lin, Y., Cheng, Y., Hsieh, M., \& Peng, W. H. (2012). Antidepressant-Like Activity of the Ethanolic Extract from Uncaria lanosa Wallich var . appendiculata
Ridsd in the Forced Swimming Test and in the Tail Suspension Test in Mice. Hindawi Publishing Corporation, 2012, 1-12.

Idayu, N. F., Hidayat, M. T., Moklas, M. A. M., Sharida, F., Raudzah, A. R. N., Shamima, A. R., \& Apryani, E. (2011). Phytomedicine Antidepressant-like effect of mitragynine isolated from Mitragyna speciosa Korth in mice model of depression. European Journal of Integrative Medicine, 18(5), 402-407.

Istriningsih, E., Khoirunnisa, K., \& Kurnianingtyas, D. I. (2018). Efek Antidepresan Kombinasi Infusa Biji Pala (Myristica fragrans) dan Daun Kemangi (Ocimum basilicum) pada Mencit Jantan Putih (Mus musculus). Parapemikir: Jurnal Ilmiah Farmasi, 72), 254-258.

Katzung, B., Masters, S., \& Trevor, A. (2013). Farmakologi Dasar dan Klinik Edisi 12 Vol 1. EGC, Jakarta, 590-597.

Lubis, A. (2008). Keanekaragaman Piperaceae Dan Rubiaceae Di Taman Wisata Alam Deleng Lancuk Kabupaten Karo Sumatera Utara. Tesis.

Lucas, M., Mirzaei, F., Okereke, O. ., Willet, W. ., O'Reilly, E. ., Koenen, K., Ascherio, \& A. (2011). Coffee, Caffeine, and Risk of Depression Among Women. Extramural Research Support, Non-U.S. Gov't]. Arch. Intern. Med., 171(17), 1571-1578.

Luliana, S., \& Islamy, M. R. (2018). Aktivitas Antinosiseptif Fraksi Diklorometana Daun Kratom ( Mitragyna speciosa Korth .) Rute Oral Pada Mencit Jantan Swiss Antinociceptive Activity of Dichloromethane Fraction of Kratom Leaves ( Mitragyna speciosa Korth .) by Oral Route In Male Swiss Mice. Jurnal Progam Studi Farmasi, Fakultas Kedokteran Universitas Tanjungpura Pontianak, 5(2), 58-64.

Moraes, R., Lima, H., Alexandrino, C., \& Cunha, M. (2020). Structural and histochemical foliar traits assessing taxonomy of Rubiaceae species occurring in the Brazilian Atlantic Forest. Flora, 268(April), 151625. 
https://doi.org/10.1016/j.flora.2020.15 1625

Narasingam, M., Vijeepallam, K., Mohamed, Z., \& Pandy, V. (2017). Anxiolytic- and antidepressant-like activities of a methanolic extract of Morinda citrifolia Linn. (noni) fruit in mice: Involvement of benzodiazepine-GABAAergic, serotonergic and adrenergic systems. Biomedicine and Pharmacotherapy, 96, 944-952.

Pechlivanova, D. M., Tchekalarova, J. D., Alova, L. H., Petkov, V. V., Nikolov, R. P., \& Yakimova, K. S. (2012). Effect of longterm caffeine administration on depressive-like behavior in rats exposed to chronic unpredictable stress. Behavioural Pharmacology, 23(4), 339-347.

Pradiningsih, A., Zuniarto, A. A., \& Maulana, N. I. (2017). Uji Efektivitas Antidepresan Suspensi Ekstrak Daun Sirsak (Annona muricata, L.) terhadap Mencit Putih Jantan. PharmaXplore Jurnal Sains Dan IImu Farmasi, 2(3), 83-93.

Puspitasari, L. (2017). Ekstrak etanol daun pandan wangi (pandanus amaryllifolius r.) $10 \%$ menurunkan immobillity time dan kadar kortisol tikus jantan galur wistar yang depresi. Intisari Sains Medis, 8(1), 24-30.

RISKESDAS. (2018). Hasil Utama Riset Kesehata Dasar. Badan Penelitian Dan Pengembangan Kesehatan.

Shewale, P. B., Patil, R. A., \& Hiray, Y. A. (2012). Antidepressant-like activity of anthocyanidins from Hibiscus rosasinensis flowers in tail suspension test and forced swim test. Indian Journal of Pharmacology, 44(4), 454-457.

Surana, A. R., \& Wagh, R. D. (2017). GC-MS profiling and antidepressant-like effect of the extracts of Hamelia patens in animal model. Bangladesh Journal of Pharmacology, 12(4), 410-416.

Swati, M., Monalisa, J., \& Abhisek, P. (2013). Evaluation of antidepressant activity of Eclipta alba using animal models. Asian Journal of Pharmaceutical and Clinical Research, 6(3), 118-120.

Szopa, A., Poleszak, E., Wyska, E., Serefko, A., Wosko, S., Wlaź, A., Pieróg, M., Wróbel,
A., \& Wlaź, P. (2016). Caffeine enhances the antidepressant-like activity of common antidepressant drugs in the forced swim test in mice. NaunynSchmiedeberg's Archives of Pharmacology, 389(2), 211-221. https://doi.org/10.1007/s00210-0151189-z

Taïwe, G., Bum, E., Dimo, T., Talla, E., Dawe, A., Moto, C. O., Sidiki, N., Désiré, P., Waard, M. De, Taïwe, G., Bum, E., Dimo, T., Talla, E., \& Weiss, N. (2011). Effects of Nauclea latifolia Smith ( Rubiaceae) Roots Extract in Murine Models To cite this version: HAL Id: inserm-00644849. International Journal of Pharmacology, 6(4), 364-371.

Tee, T. pei, \& Hassan, H. (2011). AntidepressantLike Activity of Banana Peel Extract in Mice. American Medical Journal, 2(2), 59-64.

https://doi.org/10.3844/amjsp.2011.5 9.64

Wang, W., Ma, C. M., \& Hattori, M. (2010). Metabolism and pharmacokinetics of rhynchophylline in rats. Biological and Pharmaceutical Bulletin, 33(4), 669676.

Word Health Organization. (2017). Depression an Other Mental Disorder. 48(1), 5-21.

Xian, Y., Fan, D., Ip, S., Mao, Q., \& Lin, Z. (2016). Antidepressant-Like Efect of Isorhynchophylline in Mice. Neurochem Res, 1-8.

Yusniah, A., Nur, Y., \& Ahmad, I. (2019). Ekstraksi Polifenol Total dari Daun Kadamba (Mitragyna Speciosa Korth.) Menggunakan Malic Acid-Glucose Based Microwave Assisted Extraction. Proceeding of Mulawarman Pharmaceuticals Conferences, 10,147150.

https://doi.org/10.25026/mpc.v10i1.3 81

Zhao, X., Chen, Q., Liu, Y., Xia, C., Shi, J., \& Zheng, M. (2014). Effect of xanthone derivatives on animal models of depression. Current Therapeutic Research - Clinical and Experimental, 76(2014), 45-50.

Zheng, M., Fan, Y., Shi, D., \& Liu, C. (2013). Antidepressant-like effect of 
flavonoids extracted from Apocynum venetum leaves on brain monoamine levels and dopaminergic system. Journal of Ethnopharmacology, 1471),
108-113.

https://doi.org/10.1016/j.jep.2013.02.0

15

Copyright $\odot 2020$ The author(s). You are free to Share - copy and redistribute the material in any medium or format. Adapt - remix, transform, and build upon the material. Copyrigh o 2020 The author(s). You are free to Share - copy and redist be manner, but not in any way that sugests the licensor endorses you or your use Non you remix, transform or buld upon the material you must distribute your contributions under the same license as the original. No additional restrictions - You may not you remix, transform, or build upon the material, you must distribute your contributions under the same license as
apply legal terms or technological measures that legally restrict others from doing anything the license permits. 